$14^{\text {th }}$ Conf. Agric. Dev. Res., Fac. Agric., Ain Shams Univ., March, 2019, Cairo, Egypt

Special Issue, 27(1), 83 - 92, 2019

Website: http://strategy-plan.asu.edu.eg/AUJASCI/

\title{
PERFORMANCE ANALYSIS OF MODIFIED SURFACE IRRIGATION SYSTEM BASED ON A DEVELOPED EXPERT SYSTEM
}

Basma, N. Abdeltawab ${ }^{1^{\star}}$, El-Gindy, A.M. ${ }^{2}$ and Arafa, Y.E. ${ }^{3}$

1. Agriculture Eng. Dept., Fac. of Agric., Ain Shams Univ., P.O. Box 68, Hadayek Shobra 11241, Cairo, Egypt.

*Corresponding author: Basmanasr19491@yahoo.com

Received 16 August, 2018, Accepted 9 September, 2018

\begin{abstract}
It is very difficult to find an expert at the desired time and place to give guidance about irrigation scheduling or good management of water and irrigation system. In this study, this problem was tried to be solved by designing and evaluating an expert system for a modified surface irrigation system. A rule-based program named as MSISES (Modified Surface Irrigation System by Expert System) was coded and complied using C\#.net programing language. The expert system was designed to support users with information about irrigation scheduling (irrigation operating time and irrigation interval) and the gated pipes as one of the surface irrigation modification tools (gates opening ratio). Two different experiments were held to evaluate the performance of the developed expert system. The first one is to evaluate the irrigation scheduling part by cultivating a field crop (Sweet maize) to make a comparison between the crop yield and water productivity after applying the program's scheduling and the farmer's scheduling. The second one is to make a comparison between the fully opened gates situation and when the resulted gates opening ratio is applied. The results indicated that an increase at crop yield and crop water productivity by $9.49 \%$ and $32.37 \%$ respectively for sweet maize using the developed expert system, and also, there was a slight variation between gates discharges after using the expert system except the last four gates discharge were different because of the superimposed pressure near the closed end.
\end{abstract}

Keywords: Expert system, Irrigation scheduling, Gated pipes, Modified surface irrigation system and Sweet maize

\section{INTRODUCTION}

Most of the Egyptian economics depends on agriculture field. So, yield in agricultural production has to be increased. Also, lack of water resources has led to new solutions to increase the crop productivity of cubic meters of water using modern irrigation techniques, modifying the conventional surface irrigation systems to increase water application efficiency and improving agricultural guidance services using expert systems.

lyer (2005) reported that expert systems are a type of decision support system of a software application that lends advices to its users and helping them to take better decision.

Mahmoud and Hassan (2008) said that expert system is expressed as one of artificial intelligence applications of computer program that can solve problems by simulating human reasoning process, relying on logic, belief, and rules of their opinions and experience.

Alma et al (2014) stated that expert system is an area of artificial intelligence system, which is built on the basis of deep expertise of a specific subject area. This expertise is obtained from specialists and experts in the area.

Pannu (2015) said that expert system is an area of artificial intelligence which has a huge impact on various fields of life and uses human knowledge to solve the complex problems in various fields as engineering, science, medicine and weather forecasting. 
Eid and Abdrabbo (2018) reported that expert system can be defined as artificial intelligence. It is a new science which deals with the representation, use of knowledge and automatic acquisition. Expert system is one of the newer methods that uses computer for solving practical problems in agriculture through the use of expert system.

El-Bagoury (2004) created an expert system (ISS-ES) for irrigation scheduling when using different kinds of irrigation systems (drip, sprinkler and gated pipes) under drought conditions of two sites (Bustan: the sandy soil of newly reclaimed areas; and Shalaquan: representing the alluvial soil of the Nile Delta Valley) during different months evaluation of the year for two field crops (winter crop; faba bean and summer crop; maize). The study presented all factors of variation to have significant effects on $\mathrm{ET}_{\mathrm{o}}$. The Expert system differed significantly from the two control programs. The results of cumulative water applied showed that the created expert system helped optimize the amount of consumed water that would have been overestimated in Bustan and Shalaquan.

Arafa et al (2004) built a Localized irrigation system design based on expert system technique for application priorities of Localized Irrigation Systems under various conditions of the newly reclaimed lands in northwestern regions of Egypt. They speculated that Surface Drip Irrigation System has the majority for application under different crop patterns and soils. Meantime, Bubbler and Low-head-gravity-flow bubbler irrigation systems have the usefulness for application under orchard crops; whenever, soils are affected by both salinity and high level of calcium carbonate fractions and irrigation water are low quality. The results showed that the created LIS-ES model applied the concept of dynamic programming, meaning that the proper localized irrigation system decision is selected based on qualifying all observable available evidences

El Awady et al (2002) noticed that the measured head (h) dropped slightly in the first portion of the gated pipe and this dropping ended near $21.0 \%$ of gated pipe length, because the cumulative friction head losses were greater than superimposed pressure head (h) and thus overcomes its effect. Then, the measured pressure head increased gradually until it reached the pipe end at about $96 \%$ of the original pressure head at the gated pipe inlet, because the gradual increase in (h) overcomes the effects of the cumulative friction head losses.
The advantages of modified surface irrigation system are: optimizing water use efficiency, water distribution uniformity compared to traditional surface irrigation and reducing costs with pressurized irrigation systems.

The aim of the study is to develop and evaluate an expert system for a modified surface irrigation system.

\section{MATERIALS AND METHODS}

In order to manage the gated pipe irrigation system for some field crops, a rule-based program called MSISES (Modified Surface Irrigation System by Expert System) was coded and complied using C\#.net programing language. The schematic overview shows the key input and output process and the main computational steps needed for the MSISES rule based program. The next steps outline how the MSISES program was built.

\section{Description of the program}

A soft and clear graphical user interface (GUI) is designed to give an easy use for experienced users such as agricultural guides and agricultural engineers, also to support them with decisionmaking related to irrigation scheduling and how to operate the gated pipe irrigation tool.

The MSISES rule- based program structure was designed to support users with information related to irrigation scheduling i.e. irrigation operating time and irrigation interval also to support them with information about operating the gated pipe irrigation tool or in other words the number opening gates and these gates opening ratios in order to compensate the head loss in the main pipe due to friction losses to make the gates give an approximate equal discharge for every furrow.

Figure (1) shows the developed program's main screens (opening screen, crop data screen, reference evapotranspiration $\left(E_{0}\right)$ screen, location data screen, irrigation data screen and results screen) which represent the user interface. The opening screen consists of a list of recently saved projects. The crop data screen contains the input data for crops like (crop type or name, planting date, current irrigation date, measure of rooting depth, depletion fraction, crop coefficient (Kc) values and crop development stages lengths). The reference evapotranspiration $\left(E_{0}\right)$ screen is for entering mean reference evapotranspiration for the cultivated location. 

expert system

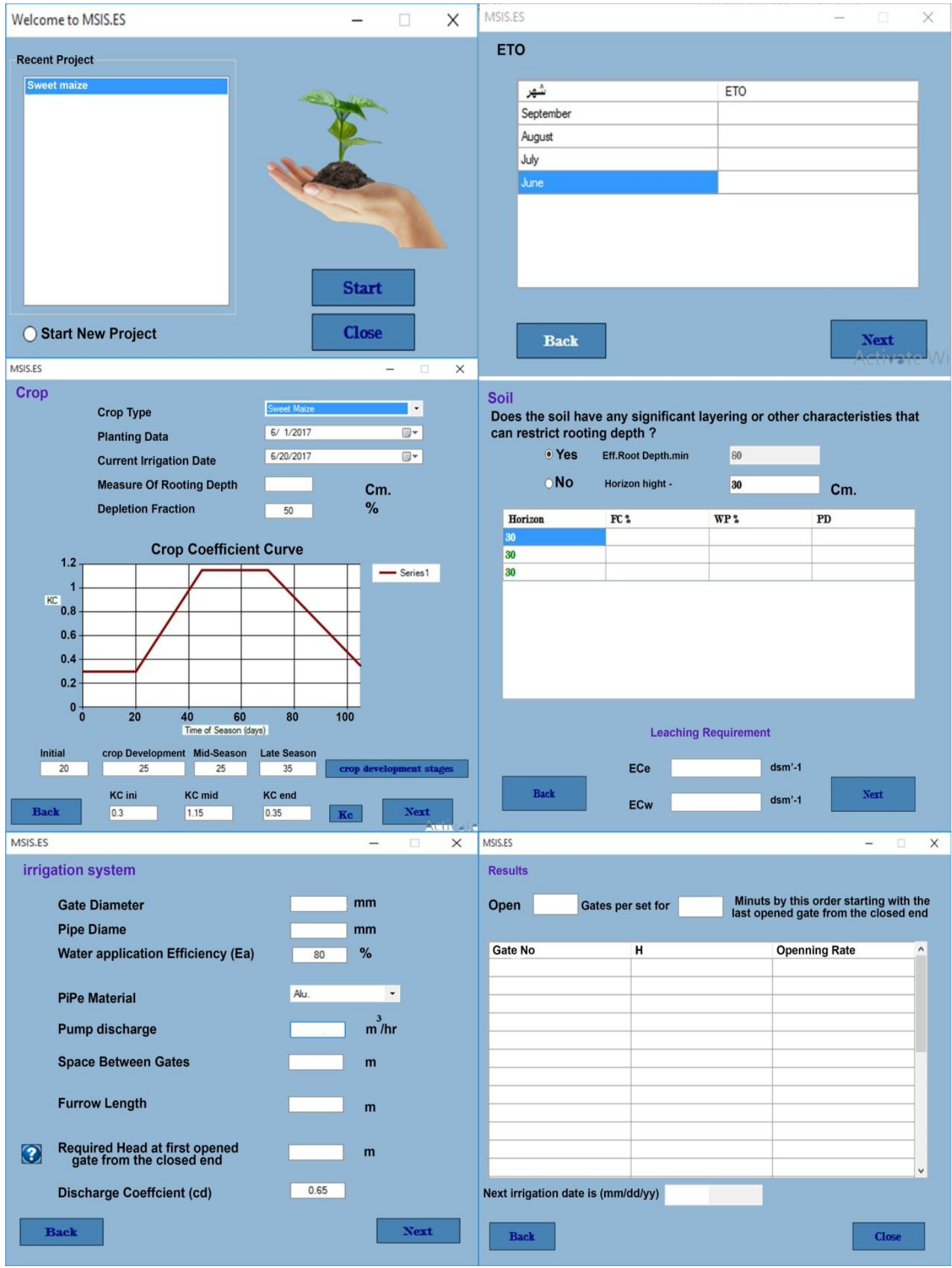

Fig. 1. The MSISES expert system user interface. 
The location data screen is divided into two sections; soil physical properties data and leaching requirement data. The irrigation data screen contains input data for gate diameter, pipe diameter, pipe material, furrow length, required head at the first opened gate from the closed end, irrigation efficiency and discharge coefficient. The results screen shows the final output values for irrigation scheduling (operating time and next irrigation date) and for number of opening gates and the opening ratios..

The user can freely go back or forward throw the previously mentioned screens. The program saves every entered value at any screen along the cultivation season in a separate project.
Figure (2) shows the MSISES program's schematic diagram which is divided into three main parts are: crop data, location data and irrigation system data. Every part has some inputs to execute the internal calculations to get the resultswhich will be used in irrigation scheduling and operating the gated pipe tool.

All entered inputs are often the same for a selected crop at every irrigation process like (crop development stages lengths, crop coefficient, furrow length and reference evapotranspiration (Eto)) except the measured rooting depth and current irrigation date inputs, they change from irrigation to another.

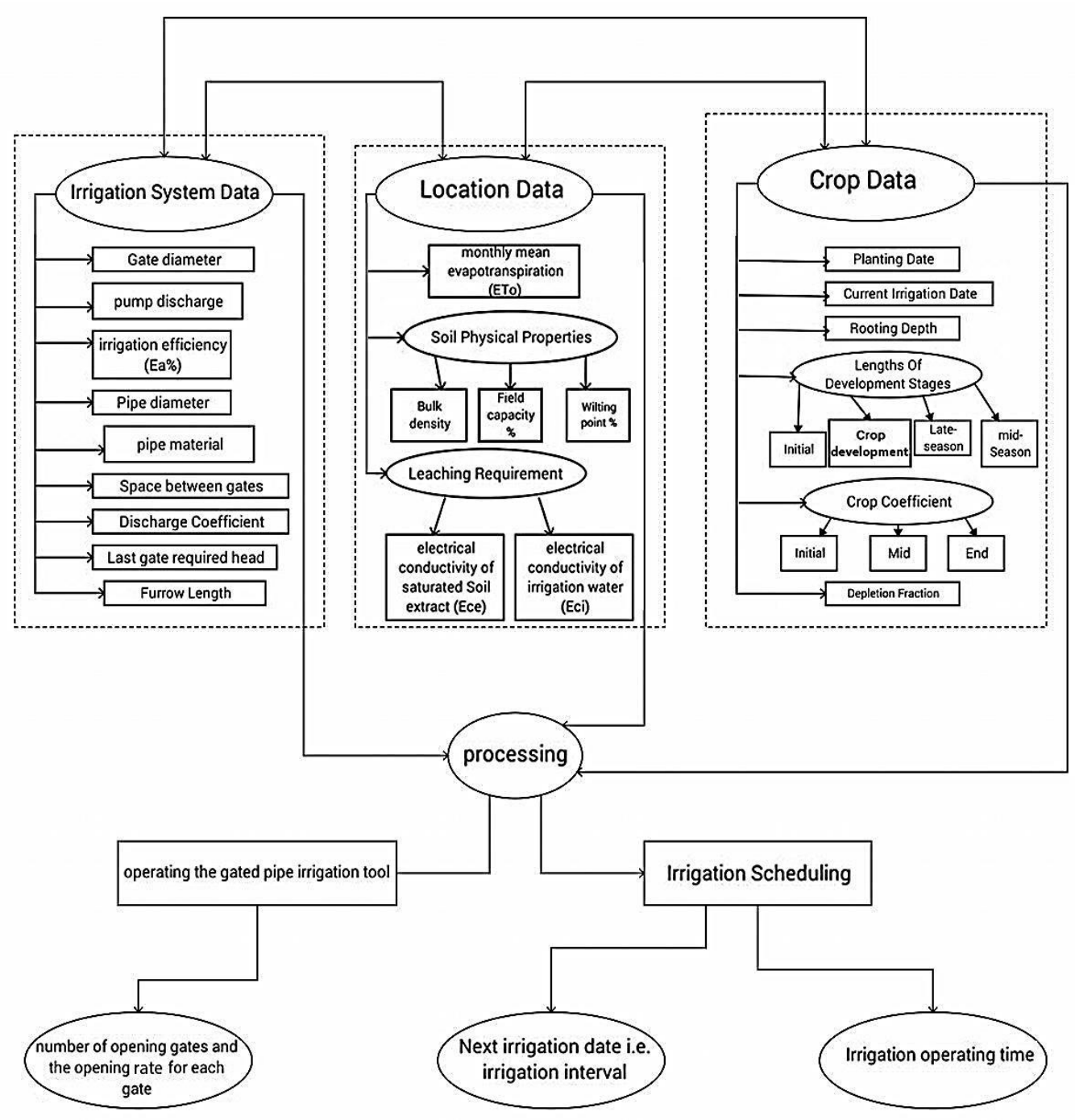

Fig. 2. Schematic diagram for the developed expert system. 
According to irrigation scheduling part, the expert system provides the user with information about the current irrigation operating time which gives the plant its need without excessive use of water or exposes the plant to thirst. Also, gives the user information about the next irrigation date or in other words the irrigation interval. The next irrigation date is figured out by calculating the water consumptions every day staring with the last irrigation date in the planting season then, adding the daily water consumption till reaches a value that is bigger than the previously calculated water requirement value.

According to gated pipe irrigation system management part, the program provides users with information about how many gates should be opened together at the desired last gate head entered by the user. Also, provides the user with every gate opening ratios that is considered to make every gate give an approximate equal discharges.

\section{The formulae used in the program}

Parameters such as: (Kc, Etc, and IR) were considered to calculate irrigation water requirement to provide user with the irrigation scheduling information.

The MSISES program depends on some equations that lead to the end results.

According to El-Gindy (2007), water requirement, irrigation requirement, water consumption, irrigation interval and operating time can be calculated from the following equations:

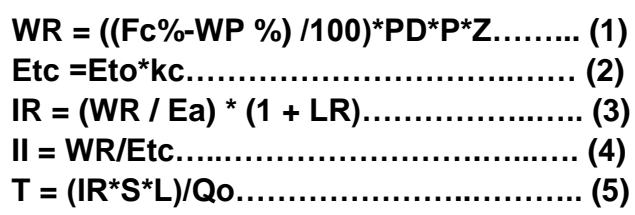

$I R=(W R / E a) *(1+L R) \ldots \ldots \ldots \ldots \ldots \ldots \ldots$ (3)

II = WR/Etc

$\mathbf{T}=\left(\mathbf{I R} \mathbf{S}^{*} \mathrm{~L}\right) / \mathbf{Q}_{0}$

Where:

- WR: water requirement, $(\mathrm{mm})$,

- FC: field capacity, (\%),

- WP: wilting point, (\%),

- $\boldsymbol{P D}$ : bulk density ,

- $\boldsymbol{P}$ : depletion fraction,

- $\boldsymbol{Z}$ : measure of rooting depth, (mm),

- Etc: water consumption, ( $\mathrm{mm} /$ day)

- Eto: reference evapotranspiration, $(\mathrm{mm} /$ day),

- $K \boldsymbol{c}$ : crop coefficient,

- Ea: water application Efficiency (equal to $80 \%),(\%)$,
- IR: irrigation requirement, $(\mathrm{mm})$,

- $\quad$ LR: leaching requirements, (\%),

- II: irrigation intervals, (days),

- $T$ : operating time for furrow irrigation system, (sec),

- S: furrow spacing or space between gates, (m),

- $\quad L$ : furrow length, $(m)$ and

- $\boldsymbol{Q}_{\boldsymbol{o}}$ : gate discharge $\left(\mathrm{m}^{3} / \mathrm{s}\right)$.

According to Rhoads (1972), leaching requirement for surface and sprinkler irrigation method can be calculated using the following equation:

$L R=\left(E c w /\left(\left(5^{\star} E c e\right)-E c w\right)\right.$. Where:

- LR: leaching requirement, (\%),

- Ece: electrical conductivity of the saturation extract of the soil, (ds $\mathrm{m}^{\wedge}-1$ ) and

- Ecw: electrical conductivity of irrigation water, (ds $\left.m^{\wedge}-1\right)$.

The gates in gated pipeline irrigation system are mainly orifices and their outflows would be expected to follow the standard orifice equation Smith, et al. (1986).

$Q_{0}=C d^{\star} 3600^{\star} A^{*}\left(2^{*} g^{\star} h\right) \wedge 0.5$.

Where:

- Qo: gate discharge, $\left(\mathrm{m}^{\wedge} 3 / \mathrm{s}\right)$,

- Cd: gate discharge coefficient (equal 0.65),

- $\boldsymbol{g}$ : gravitational acceleration (equal to 9.8), $\left(\mathrm{m} / \mathrm{s}^{2}\right)$,

- $\quad$ : : gate area, $\left(m^{\wedge} 2\right)$ and

- $\mathbf{h}$ : required pressure head at the last opened gate, $(\mathrm{m})$.

If the Hazen-Williams equation is used and the pipe is being designed for an average outflow of (Qo) from each of $\mathrm{N}$ outlets, then the total pipe friction loss $(\mathrm{Hf})$ will be given by:

$H f=L^{*} F^{\star} N^{\star}\left(V /\left(0.849^{\star} C^{\star}(D / 4) \wedge 0.63\right)\right)^{\wedge} 1.852 \ldots$ (8)

$V=\left(N^{*} Q 0\right) / A p$

$F=(1 / 1+m)+(1 / 2 * N)+\left((m-1) \wedge 0.5 /\left(6^{*} n^{\wedge} 2\right)\right) \ldots(10)$ Where:

- Hf: friction losses in the pipe (m),

- V:velocity of the flow in the upstream end of the pipe line, $(\mathrm{m} / \mathrm{s})$,

- D: pipe diameter, (m),

- L: outlet spacing, (m),

- $\mathbf{N}$ : number of outlets from the closed end,

- C: Hazen-William's coefficient (equal to 120 for Alu.), 
- F: factor accounts for the effect on friction losses of the spatial variation of the flow,

- $\mathbf{N}$ : number of opened gates at the same time,

- Qo : gate discharge, $\left(\mathrm{m}^{3} / \mathrm{s}\right)$,

- Ap : cross sectional area of the pipe line, $\left(m^{2}\right)$ and

- $\mathbf{m}=1.852$

The number of flowing gates at the same time is calculated from the following equation:

$N F G=Q t / Q 0$.

Where:

- NFG: number of flowing gates,

- Qt: pump discharge, $\left(m 3^{\wedge} h\right)$ and

- Qo: gate discharge, $\left(m^{\wedge} 3 / h\right)$

According to El-Gindy (2007), the gates discharge along the pipeline is not the same due to the friction loss along the pipe. The head is decreased along the pipe line due to the cumulative friction losses. So, if the pipe line is considered to be level, every gate head and gate opening ratio can be calculated from the following equations:

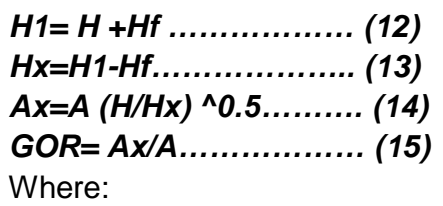

- H1 : last gate head from the closed end, (m),

- Ax: wanted gate area at any position from the last gate, $\left(m^{\wedge} 2\right)$,

- Hf: friction losses, $(m)$,

- $\mathbf{H}$ : required head at the first opened gate from the closed end, $(m)$,

- Hx : gate head at any position from the last gate, $(\mathrm{m})$ and

- GOR: gate opening ratio.

The MSISES rule-based expert system evaluation and performance analysis:

In order to evaluate the irrigation scheduling part (irrigation operating time and irrigation intervals) a control field experiment was conducted at the experimental farm of Faculty of agriculture, Ain Shams Univ., which is located at Shalakan, Kalubia governorate, Egypt and represents the alluvial soil by planting a field crop which was sweet maize (cultivar; pioneer-30k8) in order to compare the crop yield and water productivity with the neighbor farmer.

\section{Description of the field experiment}

The previously mentioned crop (planting date; $1 / 6 / 2017$ ) was cultivated in two experimental plots. The first plot was to apply the program's irrigation scheduling part (irrigation operating time and irrigation intervals) and the second plot was to apply the neighbor farmer's scheduling. Every plot consisted of 7 furrows of $40 \mathrm{~m}$ long. The space between furrows was $75 \mathrm{~cm}$ and the space between cultivated plants on the ridges was $25 \mathrm{~cm}$. the irrigation system consisted of a centrifugal pump of $80 \mathrm{~m}^{3} / \mathrm{hr}$ and Aluminum gated pipes with $12 \mathrm{~m}$ total length, $125 \mathrm{~mm}$ diameter, $75 \mathrm{~cm}$ space between gates along the pipeline and $50 \mathrm{~mm}$ outlet diameter. The head required at the first opened gate from the closed in is considered to be $0.3 \mathrm{~m}$.

The crop was harvested after 17 days from the last irrigation date for each plot. Soil samples were taken from different Soil profile depths to determine the chemical and physical properties of the soil in addition to other samples of irrigation water to determine chemical analysis of irrigation water.

The analyses were carried out in the central laboratory of faculty of Agriculture, Ain Shams University. Data are tabulated in Table (1, 2, and 3).

According to Wichelns (2014), crop water productivity is the ratio of crop yield or crop value, to a selected measure of water applied in the process of growing a crop. As such, the ratio represents the average productivity of the input, rather than the incremental productivity. For example, when the ratio of interest is the water productivity of applied water, the ratio often is calculated using equation (16).

$C W P=Y / W$

Where:

- CWP: crop water productivity, $\left(\mathrm{kg} / \mathrm{m}^{3}\right)$,

- $\quad$ : Crop yield, $(\mathrm{kg} / \mathrm{fed})$ and

- W: Applied water, (m3 /fed).

In order to evaluate the gated pipe irrigation tool part, a laboratory experiment was held at the Faculty of Agriculture Ain shams Univ. which is located in Shoubra El-Kheima, Cairo, Egypt for predicting water flow along the pipeline when all the gates are fully opened and after applying the MSISES outputs for the gates opening ratio at the same number of opened gates. 

expert system

\section{Description of the laboratory experiment}

It was carried out using zero-level Aluminum gated pipelines of $110 \mathrm{~mm}$ diameter, $40 \mathrm{~mm}$ gate outlet diameter, $24 \mathrm{~m}$ total pipe line length, $75 \mathrm{~cm}$ space between gates along the pipeline. The main pipe line flow rate or pump discharge was 58 $m^{\wedge} 3 / h$.

Outlets discharges were measured by direct method using a 10 liters bucket and stop watch. Time to fill the bucket is recorded. This process is repeated three times for each outlet and the aver- age was taken using equation (17). The flow rate is the volume of the bucket divided by the average time it took to fill the bucket equation (18).
$T_{\text {av. }}=\sum T / n$
$Q=V / T_{a v}$

Where:

- $\mathbf{T}_{\text {av: }}$ average time to fill the bucket, (sec),

- $\quad \Sigma T$ : summation of the time to fill the bucket, (sec),

- $\quad \mathbf{n}$ : number of measured points,

- $\quad$ Q: outlet discharge, (l/sec), and

- $\mathbf{V}$ : Volume of the bucket, (liter)

Table 1. Some chemical analysis of the irrigation water.

\begin{tabular}{|c|c|c|c|c|c|c|c|c|c|}
\hline $\mathbf{p H}$ & \multirow{2}{*}{$\begin{array}{c}\mathrm{EC} \\
\mathbf{1 : 2 . 5}\end{array}$} & \multicolumn{4}{|c|}{ Soluble Cations, Meq L-1 } & \multicolumn{4}{|c|}{ Soluble Anions, Meq L-1 } \\
\cline { 3 - 10 } & $\mathbf{d s} / \mathbf{m}$ & $\mathbf{C a}^{2+}$ & $\mathbf{M g}^{2+}$ & $\mathbf{N a}^{+}$ & $\mathbf{K}^{+}$ & $\mathrm{Cl}^{-}$ & $\mathbf{C O}^{3=}$ & $\mathbf{H C O}$ & $\mathbf{S O}^{\mathbf{4}}$ \\
\hline 8.50 & 0.57 & 2.8 & 1.00 & 1.70 & 0.27 & 3.50 & $\mathrm{Nd}$ & 1.60 & 0.60 \\
\hline
\end{tabular}

$\mathrm{Nd}=$ not detected

Table 2. Some chemical analysis of the soil.

\begin{tabular}{|c|c|c|c|c|c|c|c|c|c|c|}
\hline \multirow{2}{*}{ Sample depth, $\mathbf{c m}$} & PH & \multirow{2}{*}{$\mathbf{E C e}}$, & \multicolumn{3}{|c|}{ Soluble Cations, Meq L-1 } & \multicolumn{3}{|c|}{ Soluble Anions, Meq L-1 } \\
\cline { 5 - 12 } & $\mathbf{1 : 2 . 5}$ & $\mathbf{d s} / \mathbf{m}$ & $\mathbf{C a}^{\mathbf{2 +}}$ & $\mathbf{M g}^{\mathbf{2 +}}$ & $\mathbf{N a}^{+}$ & $\mathbf{K}^{+}$ & $\mathbf{C l}-$ & $\mathbf{C O}^{\mathbf{3}=}$ & $\mathbf{H C O}^{-}$ & $\mathbf{S O}^{\mathbf{4}}$ \\
\hline $0-30$ & 8.00 & 0.86 & 4.20 & 1.20 & 2.70 & 0.50 & 4.00 & $\mathrm{Nd}$ & 4.00 & 0.60 \\
$30-60$ & 7.99 & 0.66 & 3.40 & 0.60 & 2.36 & 0.29 & 2.00 & $\mathrm{Nd}$ & 2.60 & 2.00 \\
$60-90$ & 7.94 & 0.67 & 3.20 & 1.20 & 2.03 & 0.27 & 2.54 & $\mathrm{Nd}$ & 2.80 & 1.36 \\
\hline
\end{tabular}

$\mathrm{Nd}=$ not detected

Table 3. Some soil physical properties of the soil.

\begin{tabular}{|cccccccc|}
\hline $\begin{array}{c}\text { Sample } \\
\text { Depth, } \\
\text { Cm }\end{array}$ & \multicolumn{2}{c}{ Practical Size Distribution, \% } & FC, & $\begin{array}{c}\text { WP, } \\
\%\end{array}$ & $\begin{array}{c}\text { BD, } \\
\mathbf{g m} / \mathbf{c m}^{2}\end{array}$ & $\begin{array}{c}\text { Texture } \\
\text { Class }\end{array}$ \\
\cline { 2 - 4 } & Sand & Silt & Clay & & & & \\
\hline $0-30$ & 29.27 & 20.10 & 50.63 & 27.76 & 9.51 & 1.35 & $\mathrm{CL}$ \\
$30-60$ & 30.60 & 20.81 & 48.59 & 26.78 & 9.74 & 1.38 & $\mathrm{CL}$ \\
$60-90$ & 24.62 & 24.18 & 51.20 & 27.61 & 9.28 & 1.39 & $\mathrm{CL}$ \\
\hline
\end{tabular}

\section{RESULTS AND DISCUSSION}

\section{The field experiment results}

As shown in Table (4), the current irrigation dates and measured rooting depths along the cultivation season in other words the MSISES's input data at every irrigation process is tabulated for the selected crops. Every other input data were the same for the planted crop along its cultivation season.
Table 4. Measured rooting depth and current irrigation date input data at every irrigation process for sweet maize.

\begin{tabular}{|c|c|c|c|}
\hline $\begin{array}{l}\text { Crop } \\
\text { name }\end{array}$ & $\begin{array}{c}\text { Irrigation } \\
\text { no. }\end{array}$ & $\begin{array}{c}\text { Rooting } \\
\text { depth (cm) }\end{array}$ & $\begin{array}{l}\text { Current irri- } \\
\text { gation date }\end{array}$ \\
\hline \multirow{7}{*}{ 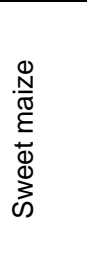 } & 1 & 19 & $20 / 6 / 2017$ \\
\hline & 2 & 26 & $28 / 6 / 2017$ \\
\hline & 3 & 35 & $9 / 7 / 2017$ \\
\hline & 4 & 43 & 21/7/2017 \\
\hline & 5 & 52 & $31 / 7 / 2017$ \\
\hline & 6 & 60 & $10 / 8 / 2017$ \\
\hline & 7 & 62 & 20/8/2017 \\
\hline
\end{tabular}

Note: the current irrigation date is also an output from the previous irrigation 
As shown in Table (5) the output data for irrigation scheduling (the irrigation operating times and the following irrigation date) are applied on the cultivated crop along the cultivation season.

Table 5. Next irrigation date and current irrigation operating times output data at the irrigation processes for sweet maize along the cultivation season.

\begin{tabular}{|c|c|c|c|}
\hline $\begin{array}{l}\text { Crop } \\
\text { name }\end{array}$ & $\begin{array}{c}\text { Irrigation } \\
\text { no. }\end{array}$ & $\begin{array}{l}\text { Next irriga- } \\
\text { tion date }\end{array}$ & $\begin{array}{l}\text { Current irriga- } \\
\text { tion operating } \\
\text { time (min) }\end{array}$ \\
\hline \multirow{7}{*}{ 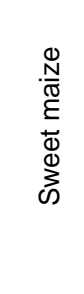 } & 1 & $28 / 6 / 2017$ & 8 \\
\hline & 2 & 9/7/2017 & 11 \\
\hline & 3 & $21 / 7 / 2017$ & 14 \\
\hline & 4 & $31 / 7 / 2017$ & 17 \\
\hline & 5 & $10 / 8 / 2017$ & 20 \\
\hline & 6 & 20/8/2017 & 23 \\
\hline & 7 & - & 24 \\
\hline
\end{tabular}

The recorded irrigation dates and irrigation operating times that were used by the farmer for cultivating the same crop is presented in Table (6).

As shown in Figure (3), a comparison between the crop yields resulted from the farmer and from MSISES application has been made.

Table 6. Farmer applied irrigation operating times and irrigation dates for sweet maize along its cultivation season.

\begin{tabular}{|c|c|c|c|}
\hline $\begin{array}{l}\text { Crop } \\
\text { name }\end{array}$ & $\begin{array}{c}\text { Irriga- } \\
\text { tion no. }\end{array}$ & $\begin{array}{c}\text { irrigation } \\
\text { date }\end{array}$ & $\begin{array}{l}\text { operating } \\
\text { time }\end{array}$ \\
\hline \multirow{7}{*}{ 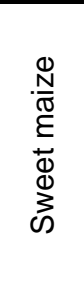 } & 1 & $20 / 6 / 2017$ & 15 \\
\hline & 2 & 3/7/2017 & 17 \\
\hline & 3 & $15 / 7 / 2017$ & 20 \\
\hline & 4 & 28/7/2017 & 20 \\
\hline & 5 & 8/8/2017 & 26 \\
\hline & 6 & $21 / 8 / 2017$ & 31 \\
\hline & 7 & $31 / 8 / 2017$ & 28 \\
\hline
\end{tabular}

Figure (3) presented that the cultivated sweet maize yield is increased by $9.49 \%$ after using the developed MSISES rule-based expert system more than the farmer so it gave a higher profitability by increasing the amount of crop production. Also, the crop water productivity or water use efficiency for the cultivated sweet maize was increased by $\mathbf{3 2 . 3 7 \%}$ after using the developed expert system more than the farmer. The application of this program helped to optimize the amount of consumed water. This result is in consistency with the created expert system by El-Bagoury (2004) for irrigation scheduling application results.

A. Sweet maize yield

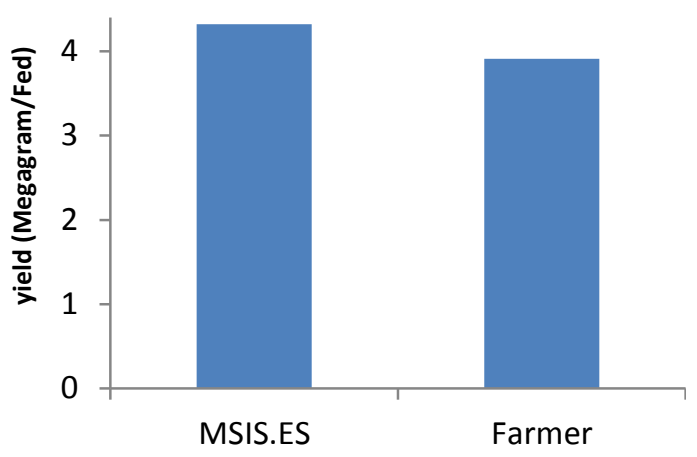

B. Sweet maize water productivity

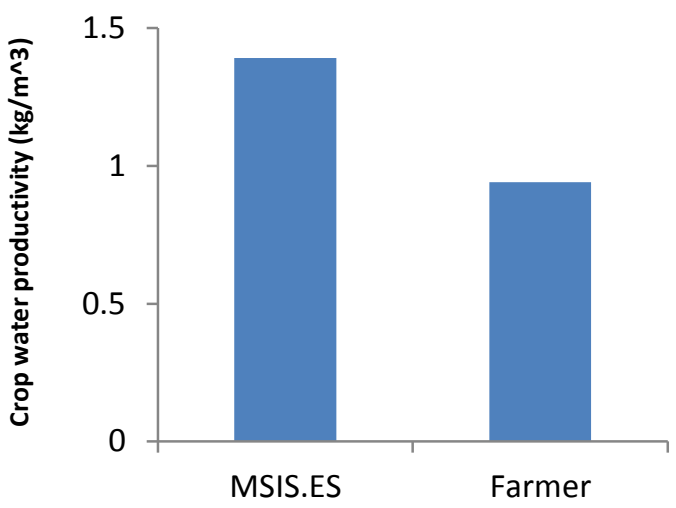

Fig. 3. Sweet maize yield and water productivity resulted from the MSIS.ES program application in comparison with the farmer

\section{The results of the laboratory experiment}

A comparison between water flow along the pipeline when all the gates are fully opened and after applying the MSIS.ES outputs for the gates opening ratio at the same number of opening gates has been made. The irrigation system input screen is presented in Plate (1). The MSISES outputs are tabulated in Table (7).

Table 7. Output data for every gate opening ratio from gate number 1 to gate number 26 .

\begin{tabular}{|c|c|c|c|c|}
\hline Gate no. & $1: 6$ & $7: 22$ & $23: 25$ & 26 \\
\hline Opening ratio & $1 / 4$ & $1 / 2$ & $3 / 4$ & full \\
\hline
\end{tabular}




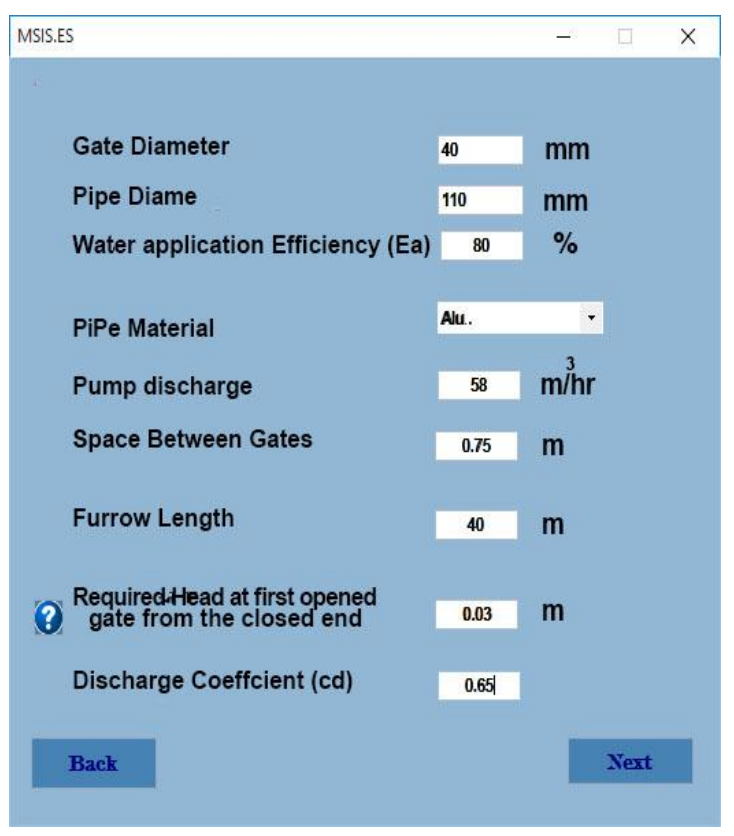

Plate 1. Irrigation system input data.
The gates discharges along the pipeline when all gates are fully opened were plotted in Figure (4). As shown in the figure, the discharges were not even and different from the ideal situation which assumed theoretically that gates discharges are exactly even. The change in the discharges is due to the change in head along the pipeline; it is slightly dropped in the first portion of the gated pipe because the friction head losses.

Then, the measured discharges increased gradually until it reached the pipe end because of the superimposed pressure head near the closed end in consistency with El Awady et al (2002).

The gates discharges along the pipeline after the application of every gate opening ratio of the MSIS.ES were plotted in Figure (5). As shown in the figure, the discharges were not the same and different from the ideal situation, but the results is more effective than the fully opened gates situation, the discharges from gate number 1 to gate number 22 were approximately equal except the last four gates.

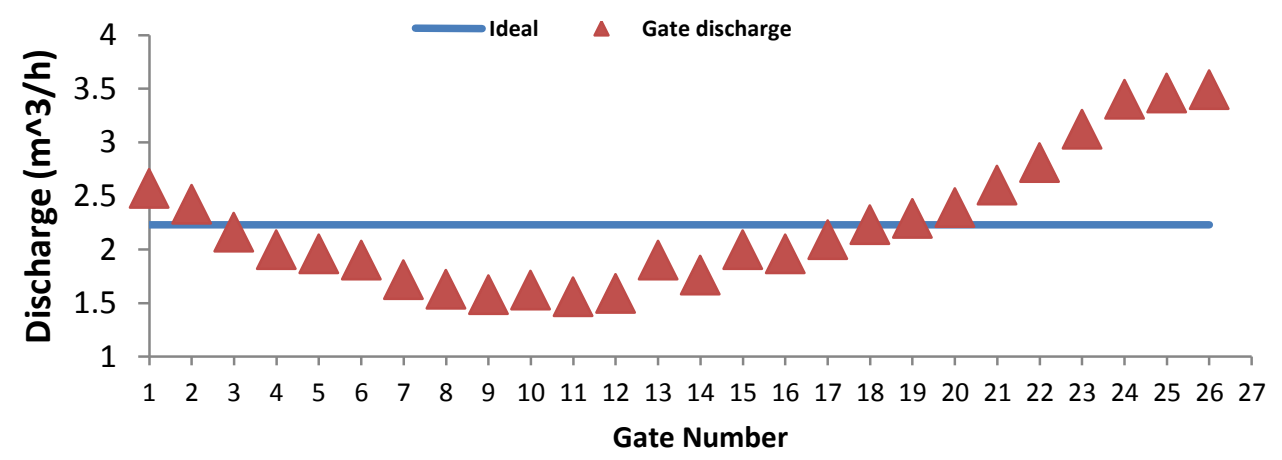

Fig.4: Gates discharges along the pipe line when all gates were fully opened.

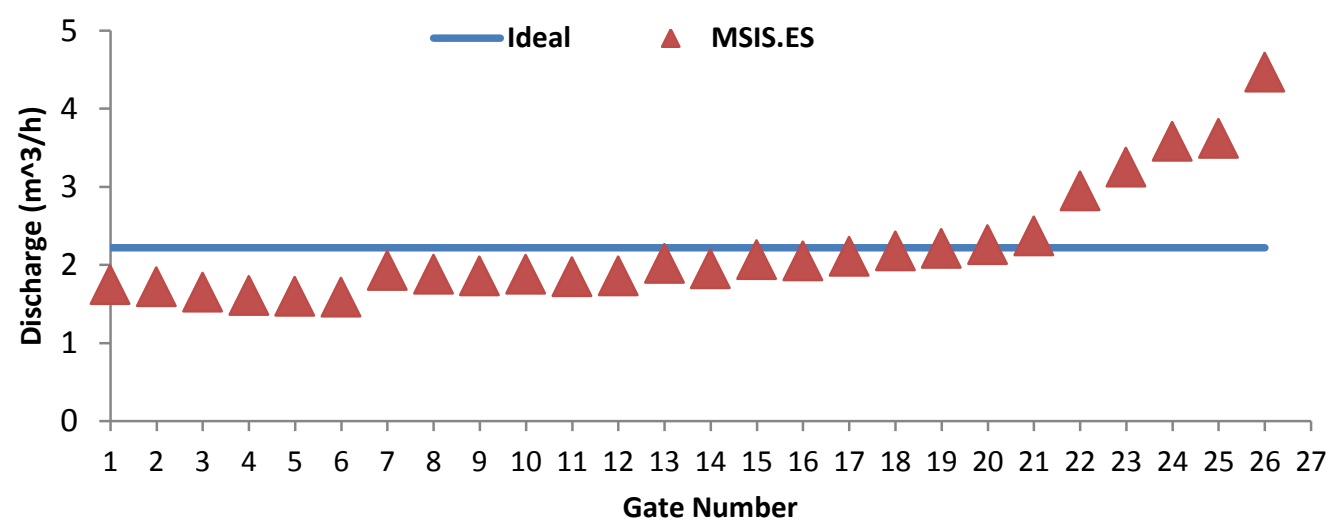

Fig. 5. The gate discharges along the pipeline after application of gate opening ratios of the MSISES. 
That could be explained by the existence of the superimposed pressure caused by the closed end, the program neglected this part.

\section{CONCLUSION}

Expert system is an alternative choice for the human expert due to the difficulties encountered in finding the expert all the time and everywhere and high costs of expert persons. Computer programs such as expert is one of the best fitting methods for finding solutions for complicated problems like the necessity of finding an expert to make proper operation of a modified surface system and proper irrigation system scheduling in order to preserve water resources and increase crop yield and water productivity. In this study, two different experiments were held in order to evaluate the developed expert system's performance. The results of the first experiment indicated that the program causes increase in crop yield and water productivity. In the second experiment, the results indicated that the program can be used for modifying the gates opening ratios. However, it misses the superimposed pressure caused by the closed end. so; the following recommendations can be made.

- The program is achieving what it meant to do except the gate opening rates part has its disadvantage as mentioned previously.

- A better economic decision can be taken within a short time.

- This expert system will help users to follow up with more than one crop at the same time

- The users don't need to input all the data at every irrigation, the program has the ability to save every step , the user may only change measured rooting depth at every irrigation and current irrigation date.

\section{ACKNOLEDGMENT}

The authors would like to thank the Academy of Scientific Research and Technology (ASRT) and Scientists for Next Generation program (SNG) for funding this research.

\section{REFERENCES}

Alma Z., Mansiya, K., Torgyn M., Marzhan M., and Kanat N., 2014. The methodology of expert systems. International Journal of Com puter Science and Network Security (IJCSNS), 14(2), 62-63.

Arafa, Y.E., Sahhar E.A.; Rafea A.A. and Gindy A.M. 2004. Expert system for application priorities of localized irrigation systems, $\mathbf{9}^{\text {th }}$ Conf. of Agric. Develop. Res., 22-24 March, Fac. of Agric., Ain Shams Univ., Cairo, Egypt, 208-218

Eid, S.F.M. and Abdrabbo M.A.A. 2018. Developments of an expert system for on-farm irrigation water management under arid conditions. J. Soil Sci. and Agric. Eng., Mansoura Univ., 9(1), 69 -76.

El-Awady, M. N., El-Tantawy M.T., Hassan S.S., and El-Ashhab A.O.M. 2002. Water-flow uniformity distribution through irrigation gated Pipes, Misr J. Ag. Eng. 19 (3), 677 - 690.

El-Bagoury, K.F. 2004. The use of expert system to improve farm irrigation technologies for maximizing water use efficiency of field crops under drought conditions in Egypt. Ph.D. Dissertation, Agric. Eng. Dept., Fac. of Agric., Ain Shams Univ., Cairo, Egypt, pp. 6670.

El-Gindy A.M. 2007. On-Farm Irrigation Systems and Technologies. ( ${ }^{\text {st }}$ Ed.), Police Press for Publishing and Distribution, Cairo, Egypt, pp. 43- 56.

Iyer, R.R. 2005. Expert System for Tree Selection in Urban Horticulture. M.Sc. Thesis, University of Florida, Florida, USA, pp. 1-58.

Mahmoud, M. and Hassan I. 2008. An integrated expert system and geographical information system. In Agriculture Domain, $3^{\text {rd }}$ National GIS Symposium in Saudi Arabia, April, 7-9, pp. 1-14.

Pannu, A. 2015. Survey on expert system and its research areas. International Journal of Engineering and Innovative Technology (IJEIT), 4(10), 104-108.

Rouds, J.D.1972. Quality of water for irrigation. Soil Sci.,113, 277-284.

Smith, R.J. and Mudler S.I. 1986. Analysis and design of gated irrigation pipelines. Agricultural Water Management, 12(1), 99-115.

Wichelns, D., 2014. Do estimates of water productivity enhance understanding of farm-level water management?. Water, 6(4), 778-795. 
المؤتمر الرابع عشر لبحوث التنمية الزراعية،

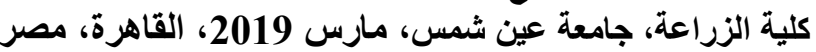

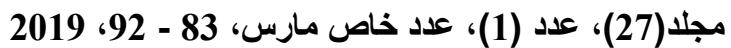

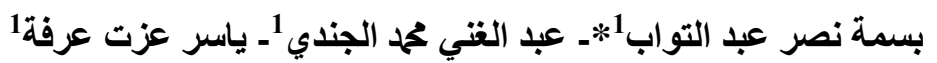

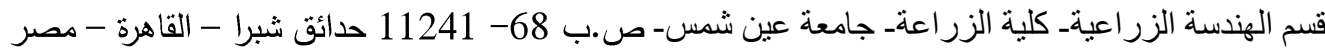

*Corresponding author: Basmanasr19491@yahoo.com

Received 16 August, 2018, Accepted 9 September, 2018

لإختبار أداء البرنامج المصمح. فكانت التجربة الاولي

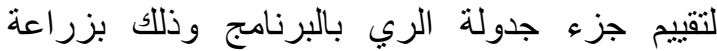
محصول حقلي ( الذرة البيضاء) لعمل مقارنة لأنتاجية

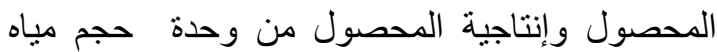
الري أو كفاءة استخدام المياه "CWP" مع إنتاجية النقان

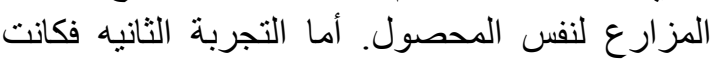

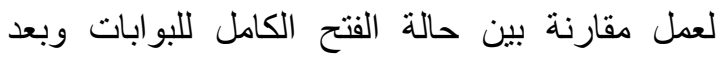

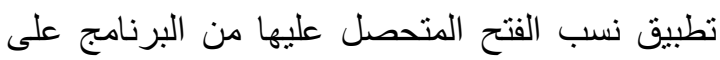
نفس البوابات. أظهرت النتائج زيادة في النتابن النتاجية المحصول المنزرع وكفاءة استخدام المياه بنسبة

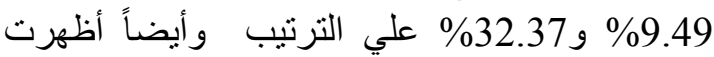
اختلاف بسيط بين معدل تصريف البوبات بعد تطبيق

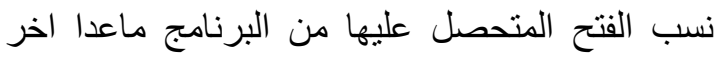

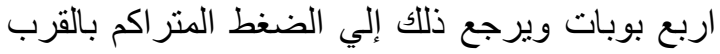
من النهاية المغلقة للأنبوبة.

الكلمات الدالة نظام خبير، جدولة الري، الأنابيب

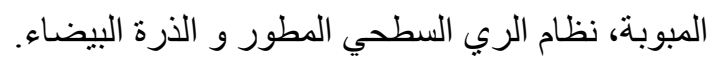

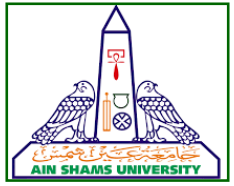

